\title{
Non-synonymous ALK Gene Mutation
}

National Cancer Institute

\section{Source}

National Cancer Institute. Non-synonymous ALK Gene Mutation. NCI Thesaurus. Code C137952.

A point mutation in the ALK gene that encodes an amino acid substitution in the ALK tyrosine kinase receptor protein. 